\title{
Anatomical and Cytological Features of Spathoglottis plicata from Java Island
}

\author{
Tatik Chikmawati*
}

Biology Department, Faculty of Matematics and Natural Sciences, Bogor Agricultural University, Bogor, Indonesia

\begin{abstract}
Spathoglottis plicata is a ground orchid that displays large variation in flower features. In spite of large variation on morphological characters, its anatomical and cytological characters are not well known. This paper described the leaf anatomical and chromosomal features of $S$. plicata. Leaf anatomy was observed from both transverse and paradermal sections of leaves. Chromosome numbers were observed from root tip cells. Epidermis of all S. plicata variants comprised of two cell shapes, the rectangle cells located above veins, while the polygonal one located in between veins. Stomatal type was brachitetracyclic, which were only found on lower epidermis. Leaf transversal section comprised of one layer of upper and lower epidermis, spongy mesophyll, and vascular tissue. The number of leaf hair varied depended on the original habitat and altitute. All variants of $S$. plicata had same chromosome number $(2 \mathrm{n}=40)$.
\end{abstract}

Keywords: anatomical, chromosome, Spathoglottis plicata variaton

\section{INTRODUCTION}

Spathoglottis plicatais an exotic ground orchid that belongs to the family Orchidaceae. This orchid is characterized by several plicate leaves arose from each pseudobulb, and tall inflorescences arose from the axil of the basal leaves. Flower has free tepals which spread widely and a trilobed lip, which is not saccate or spurred, but with two knobs near its base [1].

S. plicata is popular as ornamental plant because of its nice leaves and beautiful flowers. In addition, it has ability to adapt to unfavorable environment making it easy to grow and care it. This ground orchidis distributed in a wide environment, from area with hot temperature such as tropical area to cold temperature such as temperate area. In nature, it is found from 125 to 1650 $\mathrm{m}$ above sea level. The wider geographical distribution of plant species was correlated to the higher diversity of plant [2]. It is not surprising that $S$. plicata displays high variation in morphological characters especially its flower structure and color.

\footnotetext{
${ }^{*}$ Corresponding author:

Tatik Chikmawati

Biology Department, Faculty of Mathematics and Natural Sciences, Bogor Agricultural University, Jalan Agatis, Bogor, Indonesia16680

E-mail: tchikmawati@yahoo.com
}

Since anatomical characters and chromosome number are valuable as well as morphological characters for plant systematic study, it is interesting to know whether the high variation in morphological character of $S$. plicata followed by high variation in anatomical and cytological characters. Previous study showed that many anatomical and cytologcal characters are good to be used for species determination or solving taxonomical problem. For example, the character of leaf epidermis layer could be used to distinguish among Javanese Pandanus species [3]. This paper described the leaf anatomical character and chromosome number of $S$. plicata from Java island.

\section{MATERIALS AND METHODS}

Plant materials consisted of 40 populations of $S$. plicata collected from 18 locations in Java island and 2 population of $S$. aurrea. Leaf anatomy were observed from both paradermal and transverse sections. The leaf paradermal section were made by soaking the leave in FAA solution for 1 to 3 months, followed by soaking it in $1 \mathrm{~N}$ hydroxide solution for 1 hour, boiling it in a solution of $1 \mathrm{~N}$ chloric acid: $45 \%$ acetic acid (3:1) for 15 to 20 minutes, and then skinning (scraped) it using tweezer, and put the epidermis on a slide. The section were observed under light microscope. The observed characters were mid- 
vein, protrusion of the midvein, midvein shape, the ratio of protrusion of the midvein and midvein length, midvein tip, stomatal position and shape, the arrangement of metaxylem, upper and lower epidermis cell shape, and mesophyll cell shape. Leaf transverse section were obtained by soaking the mature leave in FAA solution (Formalin: acetic acid: $70 \%$ ethanol =3: 2: 95) for 2 to 12 weeks, then cutting them using frozen microtome, and making a slide of each slice. Both paradermal and transverse sections were stained in $1 \%$, safranine and then observed under microscope using glycerin as a medium.

Chromosome number observation was done by examining the chromosome number at metaphase of mitosis of root tips using squash method modified. Several (7-10) root tips were collected. One $\mathrm{cm}$ length of each root tip was fixed in $0.002 \mathrm{M}$ 8-hydroxyquinolin and incubated at $20{ }^{\circ} \mathrm{C}$ for 24 hour. The root tips were then moved into $45 \%$ acetic acid for 10-15 minutes, followed by soaking in a solution of $1 \mathrm{~N}$ chloric acid : $45 \%$ acetic acid $(3: 1)$ at temperature $60^{\circ} \mathrm{C}$ for 2-2.5 minutes. The root tip was then cut into 1-2 $\mathrm{mm}$ pieces, then put one piece on a slide, dropped $2 \%$ acetoorcein on it and cover it. The glas slide containing the root tip was then tapped using pencil. Chromosome numbers were observed under light microscope [4].

\section{RESULTS AND DISCUSSION}

\section{Paradermal Section}

Epidermis layer of $S$. plicata leave was generally consisted of two cell types, which were 1 . Rectangle cells located under and above veins with ratio length to width was 5: 1.2. Polygonal cells located in between veins with 4 to 6 angles, and the ratio length to width was 1-3: 1 (Figure $1 \mathrm{~A}$ and $1 \mathrm{~B})$. Polygonal cells were arranged in good order. Stomata were found only in lower epidermis layer and distributed among polygonal cells. Stomata shape was brachitetracyclic, with 4 subsidiary cells. The length of the guard cells was parallel to the leaf length. Small hairs were foundsparsely in both epidermis layers. Hairs were attached to small epidermis cells. Hair was straight, consisted of 1 to 3 cells. The cell number of hair was correlated to the hair length. The higher the cell number the longer the hair length.

\section{Transverse sections of leaves}

The characteristic of leaf transverse section were midvein very prominent, raphide cell very sparse, lobe of epidermis cells shallow, guard cells parallel to the epidermis cells, vascular shape of midveins ovate, vascular tip of midveins obtuse, the distribution of meta-xylem cells ditributed into Y pattern. S. plicata leaves were transversally differentiated into one layer of upper epidermis cells, mesophyll cells, and one layer of lower epidermis cells. The leaf surface was protected by thin cuticle with $\pm 0.6 \mu \mathrm{m}$ thick (Figure $1 \mathrm{C}$ and 1D). The diameter of epidermis cells was smaller than mesophyll cells. The lower epidermis cells was smaller than that of upper cells. Epidermis cells on the veins were also smaller that that of the other parts. The epidermis cell shape was elliptic. The mesophyll was arranged of spongy parenchyma without palisade parenchyma, and vascular bundle was distributed in it. Mesophyll cell shape was elliptic. Rhapid were sometimes found among spongy parenchyma.

All S. plicata variants had the similar anatomical characters, and there was no diagnostic anatomical characters that could differentiate among variants. Therefore, anatomical characters of $S$. plicata can not be used to judge whether the variant can be classified under species such as variety or subspecies. The similar result was also found in Artemisia [5]. They found no significant differences in the anatomy of the leaves between variety of Artemisia absinthium var. absinthium and its Polish endemic variety $A$. absinthium var. calcigena that have differences in color leaves. However, several previous results showed that anatomical characters were powerful for taxonomical purposed when it was used in the higher categories such as genus. Another research [6] was able to distinguish Cedrus atlantica, Cedrus libani, and Cedrus brevifolia using the anatomical characteristics of the needles. When we compared the anatomical character of $S$. plicata to another Spathoglottis such as $S$. aurea, we were able to easily distinguish between both species, especially from the characters of leaf transverse section, i,e. protrusion of the midvein, midvein shape, the ratio between protrusion of the midvein and midvein length, midveid tip, stomatal position, the arrangement of meta-xylem, the number of raphid cells (Table 1, Figure 1C, and 1D).

In orchids, leaf anatomy is often typical of the genus rather than the species and there are rather large groups of genera that share quite similar leaf structure. However, there was found a useful range of character variation, such as silica bodies. In our case, we found the number of raphid cells in $S$. plicata is less than that of $S$. aurea. Leaf surfaces may also provide information about the normal habitat in which the plants occur. Plants that grow in dry, or periodically dry conditions, such as epiphytic orchids, often have very thick cuticles. Conversely, plants that grow in moist or 
humid conditions, the cuticle is often thin and smooth. Within S. plicata collected from the natural habitat, hair size was influenced by plant environment. Short hairs were found in plant that grew in open environment, while long hairs were found in plant that grew among crowd bushes. Hair density varied and was influenced most by plant environment and also altitute. On the open areas, hair density was higher than that of the crowd bushes. The hair density decreased in the higher areas.

\begin{tabular}{llll}
\multicolumn{2}{l}{ Table 1. Anatomical characters of S. plicata and S. aurea } & \\
\hline No & Characters & S. plicata & S. aurea \\
\hline 1 & Protrusion of the midvein & Very prominent & Less prominent \\
2 & Vascular bundle shape of midveins & Ovate & Five angles \\
3 & Epidermis lobes & Shallow & Deep \\
4 & The position of stomatal guard cells to epidermis cells & Parallel & Prominent \\
5 & Vascular bundle tip of midveins & Obtuse & Rounded \\
6 & The widest part of midveins & Under middle & Above middle \\
7 & Meta-xilem arrangement & Y pattern & ) (Pattern \\
8 & Raphids cells & Sparse & Many \\
9 & Lamina lobes & Beringgitan & Berpicisan \\
\hline
\end{tabular}
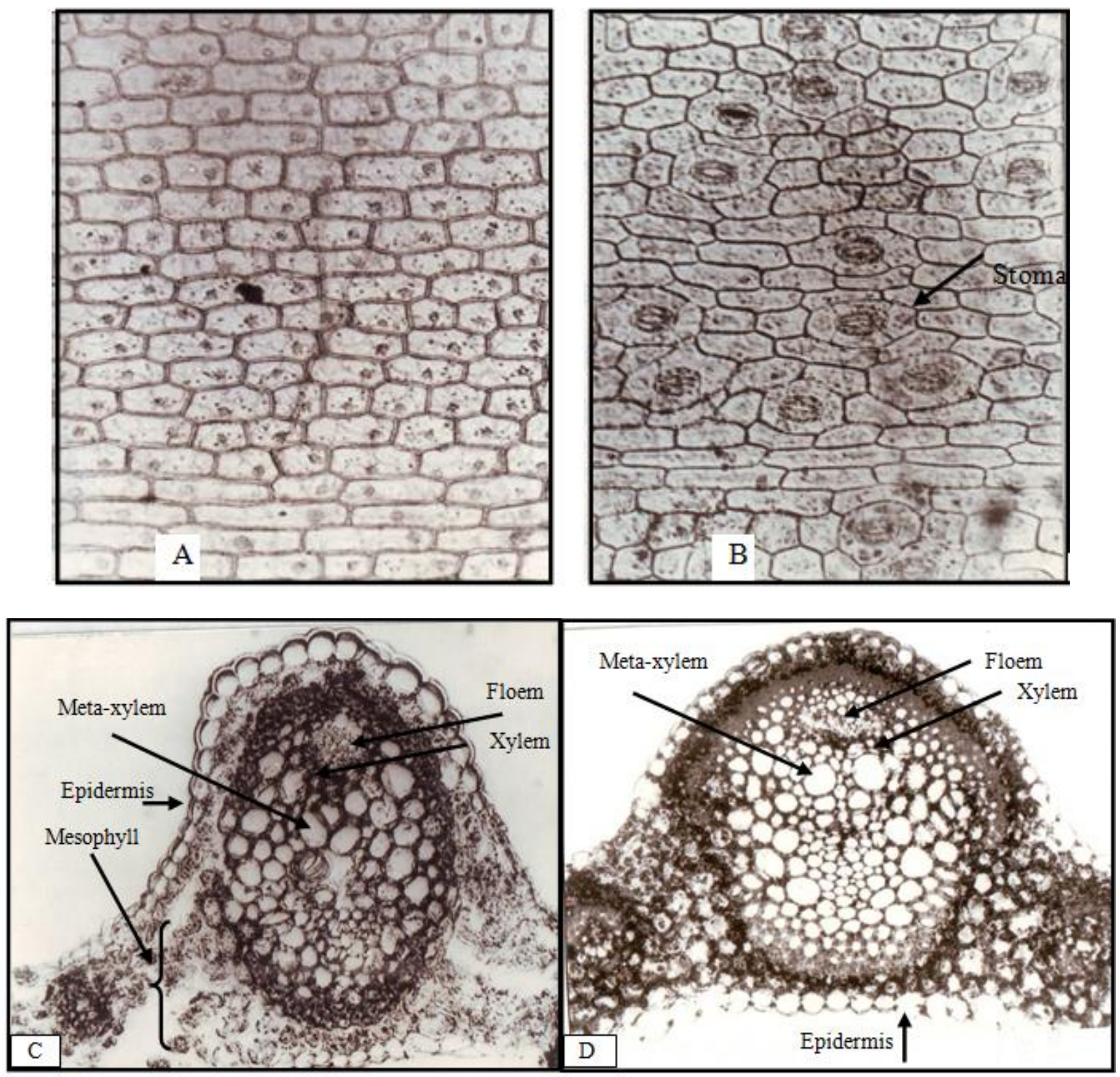

Figure 1. Leaf paradermal section upper (A) and lower (B) epidemis of $S$. plicata (40x); leaf transversal section of $S$. plicata (C) and S. aurea (D) showing the shape of midveins (10x) 


\section{Chromosome number}

Chromosome number is of particular interest because closely related species and genera often have the same number and hence a similar amount of genetic material in their tissues. All $S$. plicata variants have the same chromosome number which are $2 n=40$. This same result reported by Tanaka dan Kamemoto (1974) [7]. Previous studies also showed that most orchid genera have constant chromosome number, therefore, the most prevalent form of speciation in orchids appears to be occur without any change in the number of chromosomes. The immensely vast Dendrobium (1500 species) has very diverse morphological variations in the vegetative and floral characters, however it has only two chromosome numbers, 38 and 40 (or their multiples) [8]. Since changes in number of chromosomes between species are not so prevalent in orchids, it is to be assumed that changes within the complement are responsible for directing the course of evolution in the family. It could be brought about by hybridisation, cryptic structural changes in the chromosomes and gene mutations [10].

In spite of the tendency towards constancy of chromosome numbers in orchids, another research recorded three species of the Cymbidium have distinct inter-specific variation in the arm ratio of few homologous pairs in the complements [9]. The karyotypes of the species were more or less symmetrical. Therefore, it is interesting to know the karyotype of all $S$. plicata variants in the future. We hope that karyotype variation may be found among $S$. plicata variants.

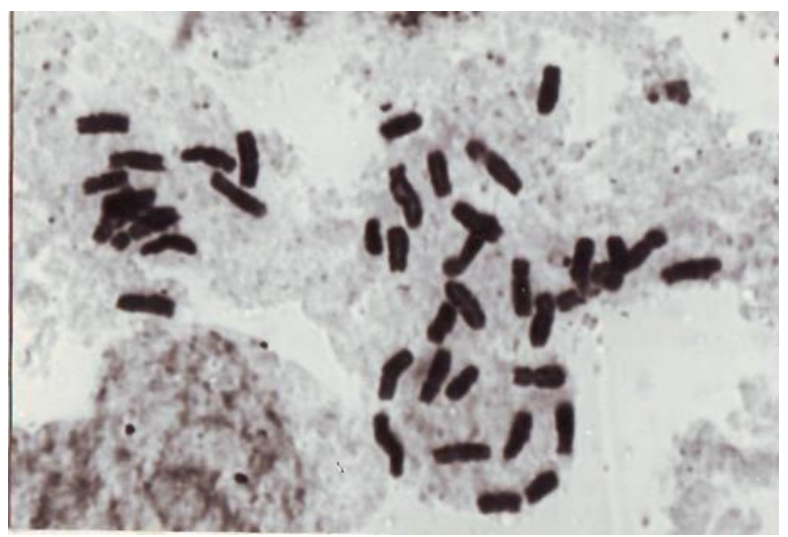

Figure 2. Chromosome of $S$. plicata $(2 \mathrm{n}=40)(100 \times)$

\section{CONCLUSION}

All S. plicata variants had the similar anatomical characters. S. plicata leaves are transersally arranged into one layer of upper epidermis cells, mesophyll cells, and one layer of lower epidermis cells. The mesophyll consisted of spongy tissue, and vascular bundle was distributed in it. Epidermis layer of $S$. plicata leave is generally arranged of two cell types, which are rectangular and polygonal cells. Stomata were found in the lower epidermis. All S. plicata variants have same chromosome number.

\section{REFERENCES}

1. Comber JB (1990) Orchids of Java, Bethammoxon Trust. Royal Botanic Gardens. Kew.

2. Lovelles MD, Hamrick JL (1984) Ecological determination of genetic structure in plant population. Annual Rev. Ecol. Syst. 15: 65-95.

3. Rahayu SE, Chikmawati T, Kartawinata K, Hartana A (2012) Leaf anatomy of Pandanus species (Pandanaceae) from Java. Plant social. and Ecol. 13 (4): 317-378.

4. Darnaedi D (1992) Kromosom dalam taksonomi. Makalah dalam kursus singkat Metodologi Penelitian Taksonomi Tumbuhan. PAU-IPB. Bogor.

5. Konowalik K., Kreitschitz A (2012) Morphological and anatomical characteristics of Artemisia absinthium var. absinthium and its polish endemic variety $A$. absinthium var. alcigena. Plant Syst. Evol. 298: 1325-1336.

6. Jasin'ska AK, Boratyńska K, Sobierajska K, Romo A, Ok T, Bou M, Kharat D, Boratyński A (2013) Relationships among Cedrus libani, C. brevifolia, and C. atlantica as revealed by the morphological and anatomical needle characters Plant Syst. Evol., 299, 35-48.

7. Tanaka R, Kamemoto H (1974) List of chromosome numbers in species of Orchidaceae. In: Withner CL, ed. The orchids. Scientific studies. John Wiley and Sons, Inc. New York.

8. Jones K, Lim KY, Cribb PJ (1982) The chromosomes of orchids VII Dendrobium. Kew Bulletin 37 (2): 221-227.

9. Sharma SK, Rajkumari K, Kumaria S, Tandon P, Rao SR (2010) Karyo-morphological characterization of natural genetic variation in some threatened Cymbidium species of Northeast India. Caryologia 63 (1): 99-105.

10. Yamagishi-Costa J, Forni-Martins ER (2009) Hybridization and polyploidy: Cytogenetic indications for Hoffmann seggella (Orchidaceae) species evolution. Int. J. Bot. 5: 93-99. 